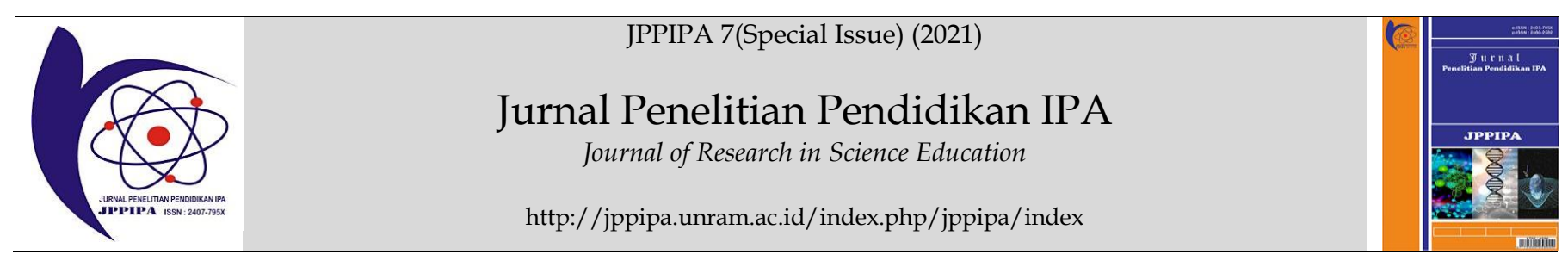

\title{
An Analysis of the Factors Influencing of Pre-service Science Teacher in Conceptualization of STEM Education: Self-Efficacy and Content Knowledge
}

\author{
Pramudya Dwi Aristya Putra ${ }^{1 *}$, Nur Ahmad ${ }^{1}$, Sri Wahyuni ${ }^{1}$, Erlia Narulita ${ }^{2}$ \\ ${ }^{1}$ Department of Science Education, Faculty of Teacher Training and Education, University of Jember, Indonesia. \\ ${ }^{2}$ Departmet of Biology Education, Faculty of Teacher Training and Education, University of Jember, Indonesia.
}

\section{DOI: $10.29303 /$ jppipa.v7iSpeciallssue.877}

\section{Article Info}

Received : August 16 ${ }^{\text {th }}, 2021$

Revised : December 2nd, 2021

Accepted: December 12th 2021

\begin{abstract}
This research investigates the factors that influence pre-service science teachers' conceptualization of STEM education. The factors involved STEM self-efficacy, STEM anxiety, science content knowledge, and mathematics content knowledge. The survey method was utilized in this research to collect a huge number of respondents at one time. The participants were 604 pre-service science teachers in Indonesia with different backgrounds (physics Education, biology education, chemistry education, Ingrate of Science education, and primary school education). The instruments were developed and share with participants using a google form to avoid the items that the participant did not fill in. The data analyzed using STEM showed that science content knowledge, STEM self-efficacy, and STEM anxiety were influencing the conceptualization of STEM education. This research suggested that to improve the quality of STEM education in the classroom. Pre-service science teachers should understand the concept of the content taught.
\end{abstract}

Keywords: factors on STEM education; STEM; Self-efficacy; and content knowledge

Citation: Putra, P. D. A., Ahmad, N., Wahyuni, S., \& Narulita, E. (2021). An Analysis of the Factors Influencing of Pre-service Science Teacher in Conceptualization of STEM Education: Self-Efficacy and Content Knowledge. Jurnal Penelitian Pendidikan IPA, 7(SpecialIssue), 225-230. https:/ / doi.org/10.29303/jppipa.v7iSpecialIssue.877

\section{Introduction}

The integration of science, technology, engineering, and mathematics has been explored in the research in the Indonesian context. For example, Mutakinati, et al. (2018) implemented STEM education to boost the critical thinking skills of a junior high school student. Other research from Sulaeman, et al. (2021) focuses on the infused of engineering design on STEM education. That research reinforces that STEM education is still a recent issue in science education.

To support the implementation of STEM education, educators should develop specific skills that express STEM pedagogical knowledge (Wojnowski \& Pea, 2014). The integration of STEM knowledge must be included in these skills. Additionally, the ability to develop a design solution in an engineering context also gives a varying understanding of STEM education (Rinke, et al., 2016). The point in the knowledge of STEM education for a teacher is that preparation of the preservice science teacher to teach STEM effectively in the classroom is also necessary to be conducted (Bybee, 2013; Erdogan \& Ciftci, 2017). Research on STEM education suggested that the mastery of content knowledge and teacher belief improved the quality of teacher's ability to teach STEM in the classroom (McFadden \& Roehrig, 2019). Content knowledge has the rule to connect between subjects in the STEM concept. Instance, research found that the way to teach STEM could be started as a science context to develop

\footnotetext{
*Email: pramudya.fkip@unej.ac.id
} 
STEM learning stages in technology and mathematics (Ring, et al., 2017). However, the pre-service science teachers' understanding of multidisciplinary subjects such as science and mathematics was lacking. Treating STEM education has no adequate confidence to develop STEM instructional design (Pimthong \& Williams, 2018).

The mastery of teachers toward subject matter has an essential role in running STEM education for the future. Furthermore, Gess-Newsome (2015) claimed that mastery of content subject matter knowledge could better influence the delivery of content to students because teachers have high self-efficacy.

Self-efficacy is a cognitive and behavioral theory that is commonly known as social cognitive theory. This theory appears from the interaction between beliefs, behaviors, and environment (Bandura, 1999). Then, the teacher's self-efficacy indicated the teacher's confidence in influencing students' learning (Guskey \& Passaro, 1994; Hammack \& Ivey, 2017). Teacher self-efficacy in STEM education can improve students' understanding of STEM education (NRC, 2012). Some research was conducted to investigate the interrelationships between self-efficacy and teacher knowledge of STEM education.

The research on STEM self-efficacy has been developed, creating an instrument to convince the understanding of STEM education for the STEM teachers. For example, Hammack \& Ivey (2017) utilized teacher's engineering of self-efficacy to explore the teacher's understanding of STEM education. In the finding, low teacher performance on the engineering self-efficacy and pedagogical knowledge to infuse the engineering in STEM education. Other research DeCoito \& Myszkal. (2018) suggested that the STEM pedagogical knowledge should be investigated in the relation between teacher mastery of content knowledge, teacher belief, and the understanding of STEM concepts.

There are several concepts on STEM education that have been found in recent research. The concept starts with STEM as a single subject, STEM as multidiscipline, STEM as inter-discipline, and STEM as trans-discipline (Roehrig, et al., 2021). Before the research about the conceptualizing of STEM education, several concepts about bridge to integrating between the concept of science, technology, engineering, and mathematics have been found (Ring, et al., 2017). The bridge also included the real-world problem as an integrating in STEM discipline (Johnson, 2013; Stohlmann, et al., 2012). Therefore, the practices in STEM education require problem-solving skills and inquiry-based instruction for the students.
This research aims to explore the factors that influence of conceptualization of STEM education to Indonesian pre-service science teachers. The questions research was developed to guide this research: What is the relationship between STEM self-efficacy and content knowledge towards the understanding of pre-service science teachers toward STEM education?

\section{Methods}

This research utilized the survey methods to investigate the correlation between pre-service science teachers' conceptualization in STEM education, STEM self-efficacy, STEM anxiety, science content knowledge, and math content knowledge. The survey was in this method because this research was addressing to collect a huge number of participants.

The number of participants in this research was 604 pre-service science teachers collected from five universities on one island in Indonesia. The selected university must meet the criteria which had been set before. One of the criteria should have STEM subjects in their curriculum so that pre-service science teachers understand STEM education practices. The participants are also from different backgrounds in the third year of four-year program in the bachelor's degree. The total number of participants was shown in Table 1.

Table 1. Participants in this research

\begin{tabular}{lll}
\hline Background & $\mathrm{N}$ & Total $(\%)$ \\
\hline Physics & 211 & 35 \\
Biology & 99 & 26 \\
Chemistry & 40 & 7 \\
Integrated science & 115 & 19 \\
Primary school education & 139 & 23 \\
\hline
\end{tabular}

The instruments were developed in several items, including STEM self-efficacy, STEM anxiety, science content knowledge (focus on the energy), math content knowledge (focus on the algebra), and conceptualization of STEM education. The instrument used the Likert Scale in points 1 (strongly agree) - 6 (strongly disagree). Those instruments were shared with the participants using a google form to get the result quickly and accurately. The advantage in this way was that the pre-service science teacher should answer all the questions given without an empty one of them. Table 2 indicates the meaning of the factors. 
Table 2. The definition of the factor used in this research

\begin{tabular}{ll}
\hline Factors & Definition \\
\hline STEM self-efficacy & Teacher's ability to make sure for students' understanding of STEM \\
STEM anxiety & The loss of confidence in STEM education \\
Energy Content knowledge & $\begin{array}{l}\text { The mastery of the material in natural science (this research focuses on the } \\
\text { energy concepts) }\end{array}$ \\
Mathematics content knowledge & $\begin{array}{l}\text { The mastery of content knowledge in mathematics concepts (this research was } \\
\text { algebra) }\end{array}$ \\
Conceptualization of STEM education & Teacher understanding of STEM concepts \\
\hline
\end{tabular}

Structural Equation Modelling (SEM) was used to analyze the result in this research. SEM informed the correlation between factors so that it could be studied more in detail. The criteria fix the model in SEM was following from the Byrne (2012). A model will be valid when the model meets with a specific character. (1) RMS value less than 0.05 ; (2) GFI and AGFI close to 1 (Jöreskog \& Sörbom, 1993); (3) PGFI value 0.05; (4) RMSEA less than 0.05 (MacCallum et al., 1996); (5) PCLOSE more than 0.50 .

The SEM was implemented to evaluate the theoretical model that investigates the way factors influenced of conceptualization of STEM. Using the SEM analysis could represent a path diagram that estimated a regression of structural relationship between factors (Mueller, 1999).

The hypothesis in this research was the relationship between the factors. The STEM self-efficacy, STEM anxiety, Science content knowledge, mathematics content knowledge would influence of conceptualization of STEM education.

\section{Result and Discussion}

The research purpose was to explore the connection between STEM self-efficacy, STEM anxiety, and STEM conceptualization. The hypnotize model was described in Figure 1.

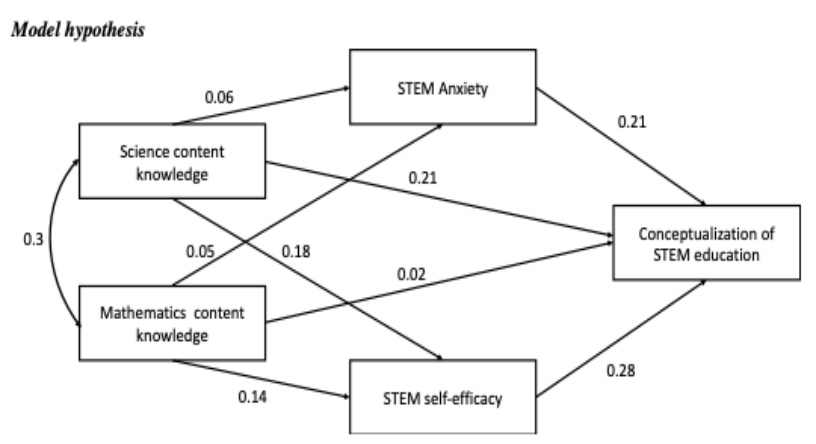

Figure 1. The model of the hypothesis that correlation between the factors

Based on the Figure 1. the model was evaluated with SEM. The fit model was valid with the analysis: $x^{2}(37) 43.970 \mathrm{P}<0.05=0.00 \mathrm{GFI}=962$; AGFI = 930; PGFI
$=540 ; \mathrm{CFI}=930 ; \mathrm{RMSAE}=0.029 ; \mathrm{PCLOSE}=0.818$. This fit model showed that the correlation between factors could be analysis in detail in Table 3.

Table 3. the correlation between factors

\begin{tabular}{llllllll}
\hline Factors & Min & Max & Mean & A & B & C & D \\
\hline A & 1 & 6 & 4.46 & & & & \\
B & 1 & 6 & 4.05 & $.23^{*}$ & & & \\
C & 2 & 6 & 4.21 & $.26^{*}$ & $.18^{*}$ & & \\
D & 1 & 5 & 3.28 & .07 & $.06^{*}$ & $-.19^{*}$ & \\
E & 2 & 5 & 4.20 & $.28^{*}$ & .07 & $.31^{*}$ & $.12^{*}$ \\
\hline
\end{tabular}

Note: $\mathrm{A}=$ Science content knowledge, $\mathrm{B}=$ Math content Knowledge, $C=$ STEM self-Efficacy, $D=S T E M$ anxiety, E= STEM conceptualization; *the correlation is significant at 0.05 level (2-tailled)

The correlation between the factors was shown in the SEM model that the conceptualization of STEM education was influenced by science content knowledge, STEM self-efficacy, and STEM anxiety. The STEM selfefficacy and STEM anxiety had a negative correlation between them. Furthermore, the math content knowledge was no correlated to STEM self-efficacy. The example of the items that showed the STEM conceptualization described in figure 2 .

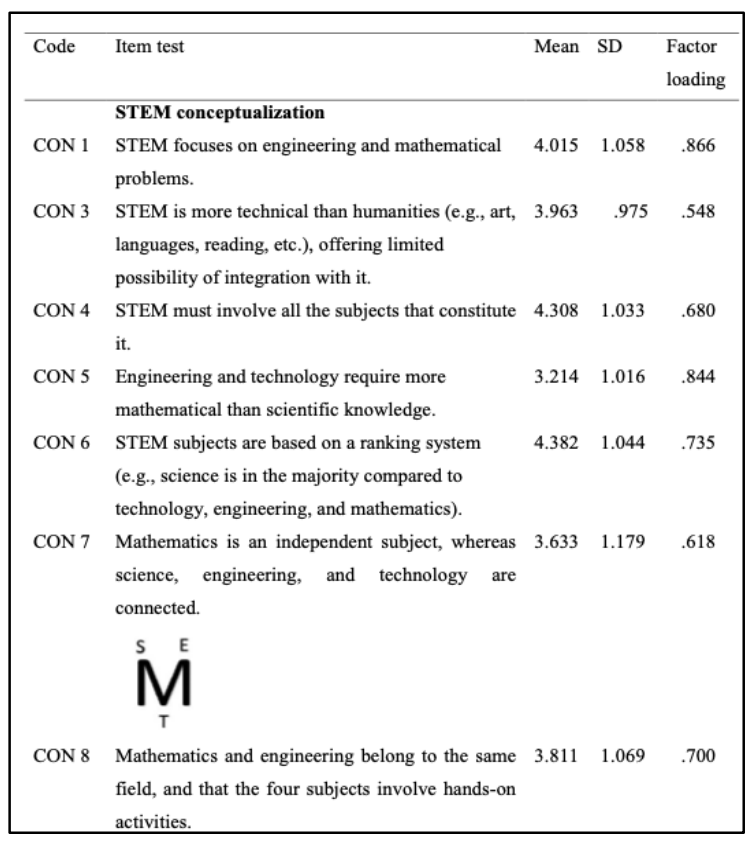

Figure 2. the example of items in STEM Conceptualization 
This study was focus on the investigation of factors that influenced the conceptualization of STEM education. The results showed that not all factors were significant to influence the conceptualization of STEM education. Three factors give a positive correlation to the conceptualization of STEM education for pre-service science teachers.

The pre-service science teachers should mastery on the content knowledge because content knowledge was the essential element to be taught in a classroom. Stohlmann, et al. (2012) stated that the STEM education center is an integration between the subjects. This way is the key to success in the implementation of STEM education. Also, in STEM education, pre-service science teachers should learn mastery of content knowledge. The results were in resonance with the previous study that the implementation of STEM education needs the support of STEM content knowledge (Putra \& Kumano, 2018). The more advanced content knowledge in STEM education facilitates pre-service science teachers to connect the concepts thought in the classroom (Kelley \& Knowles, 2016). For example, in this research, the focus of content for pre-service science teachers was on energy. The concept was tested for the pre-service science teacher in one aspect of energy and gave the crosscutting concept between energy in physics, chemistry, and biology. This finding might suggest that more content knowledge training for pre-service science teachers would improve quality for STEM teachers.

The content knowledge also gave a direction fluency in their STEM conceptualization and selfefficacy. Palmer et al. (2015) found that the understanding of content knowledge for pre-service science teachers improved their confidence to teach science and STEM education in the classroom. Hammack \& Ivey (Hammack \& Ivey, 2017) could develop an instructional design well for the classroom when the pre-service science teacher has sufficient knowledge about the content. Additionally, the preservice science teacher most effectively implemented STEM education at the school when they mastered content knowledge (DeCoito \& Myszkal, 2018). The result was strengthened by Bandura (1988) that selfefficacy had a positive effect on individual performance. This situation supports the study on this research that conceptualization of STEM education might improve the pre-service science teacher performance because of their understanding of STEM content knowledge and their confidence to bring STEM education approach in the classroom.

Mastery in science and mathematics content knowledge was not described as a significant relationship toward STEM anxiety. It meant that the mastery of science content knowledge and mathematic content knowledge did not directly affect the anxiety of pre-service science teachers on STEM education. However, this research shows that STEM anxiety influences pre-service science teachers' understanding to conceptualize STEM education. Senler's. (2016) study supports that the pre-service science teacher's anxiety about something would influence the pre-service science teacher's ability to teach science in the classroom. This research emphasized that anxiety for pre-service science teachers cloud give effect pre-service science teacher understanding about STEM education. This research did not involve a mathematics background for the participants. For this reason, it provides a result that mathematics content knowledge was not significant toward the conceptualization of STEM education.

When conducting the research, the limitation rose in the result only describing the understanding of preservice science teachers toward STEM education. The methods for investigating the pre-service science teacher's ability to teach STEM education in the classroom need to be explored to give a more profound understanding of the factors influencing STEM education. Other methods such as observation or interview need to be developed to explain the implementation of STEM education in the classroom. However, there is no education policy to apply the STEM education approach in the classroom.

\section{Conclusion}

This research was informed that an SEM of factors influenced the Indonesian pre-service science teachers' STEM education to conceptualize STEM education. The significant study described that content knowledge has an important rule to integrate between STEM subjects. Additionally, the mastery of teachers in content knowledge could improve the STEM self-efficacy for pre-service science teachers. The Anxiety of STEM education should control the pre-service science teachers because this factor can lose the pre-service science teacher's confidence in the understanding of STEM education.

\section{Acknowledgments}

This research was granted from the University of Jember finding with the contract number: 2810/UN25.3.1/LT/2021

\section{References}

Bandura, A. (1988). Self-efficacy conception of anxiety. Anxiety Research, 1(2), 77-98. https://doi.org/10.1080/10615808808248222 
Bandura, A. (1999). Social cognitive theory of personality. In W. M. Kurtines \& J. L. Gewirtz (Eds.), Handbook of personality (Vol. 2, pp. 154-196). L a w r e n c e E r l bu m A s ociates.

Bybee, R. W. (2013). The Case for STEM Education Challenges and Opportunities. NSTA Press.

Byrne, B. M. (2012). Structural equation modeling with Mplus: basic concepts, applications, and programming. In Multivariate applications series. Routledge.

DeCoito, I., \& Myszkal, P. (2018). Connecting Science Instruction and Teachers' Self-Efficacy and Beliefs in STEM Education. Journal of Science Teacher Education, 29(6), 485-503. https://doi.org/10.1080/1046560X.2018.1473748

Erdogan, I., \& Ciftci, A. (2017). Investigating the Views of Pre-Service Science Teachers on STEM Education Practices. International Journal of Environmental and Science Education, 12(5), 10551065.

Gess-Newsome, J. (2015). A model of teacher professional knowledge and skill including PCK: Results of the thinking from the PCK Summit. In A. Berry, P. Friedrichsen, \& L. John (Eds.), Re-examining Pedagogical Content Knowledge in Science Education (Teaching a, pp. 20-42). Routledge.

Guskey, T. R., \& Passaro, P. D. (1994). Teacher Efficacy: A Study of Construct Dimensions. American Educational Research Journal, 31(3), 627-643. https://doi.org/10.3102/00028312031003627

Hammack, R., \& Ivey, T. (2017). Examining Elementary Teachers' Engineering Self-Efficacy and Engineering Teacher Efficacy. School Science and Mathematics, 117(1-2), 52-62. https://doi.org/10.1111/ssm.12205

Johnson, C. C. (2013). Conceptualizing Integrated STEM Education. School Science and Mathematics, 113(8),

367-368. https://doi.org/10.1111/ssm.12043

Jöreskog, K. G., \& Sörbom, D. (1993). LISREL 8: Structural equation modeling with the SIMPLIS command language. In LISREL 8: Structural equation modeling with the SIMPLIS command language. Lawrence Erlbaum Associates, Inc. Retrieved from. https://psycnet.apa.org/record/1993-97878-000

Kelley, T. R., \& Knowles, J. G. (2016). A conceptual framework for integrated STEM education. International Journal of STEM Education, 3(1). https://doi.org/10.1186/s40594-016-0046-Z

MacCallum, R. C., Browne, M. W., \& Sugawara, H. M. (1996). Power analysis and determination of sample size for covariance structure modeling. Psychological Methods, 1(2), 130-149. https://doi.org/10.1037/1082-989X.1.2.130
McFadden, J., \& Roehrig, G. (2019). Engineering design in the elementary science classroom: supporting student discourse during an engineering design challenge. In International Journal of Technology and Design Education 29(2). Springer Netherlands. https://doi.org/10.1007/s10798-018-9444-5

Mueller, R. O. (1999). Basic principles of structural equation modeling: An introduction to LISREL and EQS. Springer Science \& Business Media. Retrieved from.

https://link.springer.com/book/10.1007/978-1$\underline{4612-3974-1}$

Mutakinati, L., Anwari, I., \& Yoshisuke, K. (2018). Analysis of students' critical thinking skill of middle school through stem education projectbased learning. Jurnal Pendidikan IPA Indonesia, $7(1), 54-65$. https://doi.org/10.15294/jpii.v7i1.10495

NRC. (2012). STEM Integration in K-12: Status, prospects, and an agenda for research engineering. The National Academic Press.

Palmer, D., Dixon, J., \& Archer, J. (2015). Changes in science teaching self-efficacy among primary teacher education students. Australian Journal of Teacher Education, 40(12), 26-40. https://doi.org/10.14221/ajte.2015v40n12.3

Pimthong, P., \& Williams, J. (2018). Preservice teachers' understanding of STEM education. Kasetsart Journal of Social Sciences, 1-7. https://doi.org/10.1016/j.kjss.2018.07.017

Putra, P. D. A., \& Kumano, Y. (2018). Energy Learning Progression and STEM conceptualization among pre-service science teachers in Japan and Indonesia. New Educational Review, 53(3), 153-162. https://doi.org/10.15804/tner.2018.53.3.13

Ring, E. A., Dare, E. A., Crotty, E. A., \& Roehrig, G. H. (2017). The Evolution of Teacher Conceptions of STEM Education Throughout an Intensive Professional Development Experience. Journal of Science Teacher Education, 28(5), 444-467. https://doi.org/https://doi.org/10.1080/104656 0X.2017.1356671

Rinke, C. R., Gladstone-Brown, W., Kinlaw, C. R., \& Cappiello, J. (2016). Characterizing STEM Teacher Education: Affordances and Constraints of Explicit STEM Preparation for Elementary Teachers. School Science and Mathematics, 116(6), 300-309. https://doi.org/10.1111/ssm.12185

Roehrig, G. H., Dare, E. A., Ring-Whalen, E., \& Wieselmann, J. R. (2021). Understanding coherence and integration in integrated STEM curriculum. International Journal of STEM Education, 8(1), 2. https://doi.org/10.1186/s40594-020-00259-8 
Senler, B. (2016). Pre-service science teachers' selfefficacy: The role of attitude, anxiety and locus of control. Australian Journal of Education, 60(1), 2641. https://doi.org/10.1177/0004944116629807

Stohlmann, M., Moore, T., \& Roehrig, G. (2012). Considerations for Teaching Integrated STEM Education. Journal of Pre-College Engineering Education Research, 2(1), 28-34. https://doi.org/10.5703/1288284314653

Sulaeman, N. F., Putra, P. D. A., Mineta, I., Hakamada, H., Takahashi, M., Ide, Y., \& Kumano, Y. (2021). Exploring Student Engagement in STEM Education through the Engineering Design Process. Jurnal Penelitian dan Pembelajaran IPA, 7(1), 1. https://doi.org/10.30870/jppi.v7i1.10455

Wojnowski, B. S., \& Pea, C. H. (2014). Models and approaches to STEM professional development. NSTA Press. 